\title{
Company Financial Performance Analysis (Case Study at PT Matahari Department Store and PT Ramayana Lestari Sentosa Tbk )
}

\begin{abstract}
Elin Paulina*
${ }^{1}$ Accounting Study Program, Faculty of Business and Humanities, Nusa Putra University, Indonesia

*Corresponding author.Email: elin.paulina@nusaputra.ac.id

\section{ABSTRACT}

To see a financial performance during this Pandemic, the Liquidity Ratio, Solvency Ratio, and Activity Ratio were analyzed. This analysis aims to see the financial performance of two companies, namely PT Matahari Department Store and PT Ramayana Lestari Sentosa Tbk. The research results show that the Current Ratio Liquidity Ratio of PT Ramayana Lestari Sentosa is 3.2\%, while PT Matahari Department Store has a current ratio of 1.1\%. The solvency ratio of PT Ramayana Lestari Sentosa is safe because the result is 1\%, it is stated that assets can cover the debt. Moreover, the Activity Ratio of PT Matahari Department Store and PT Ramayana Lestari Sentosa is declared to have decreased because the results from these 3 years are relatively low. After all, the present results are below 1 or $100 \%$.
\end{abstract}

Keywords: Financial Performance, Liquidity Ratio, Solvency Ratio, Activity Ratio.

\section{INTRODUCTION}

Nowadays, every industry wants its company to grow and compete with other sectors. A company can be said to achieve success and win the competition if it can generate maximum profit. It is undeniable that profit growth is inseparable from the company's financial performance. One of the most frequently used financial analysis tools is financial ratios. Financial ratios compare the numbers contained on the balance sheet and income statement [1].

At the end of this year, the retail industry has provided fashion equipment, accessories, beauty to household items at affordable prices. Still, during this Pandemic, the retail sector, especially PT Ramayana Lestari Sentosa Tbk, faced a significant decline in revenue to IDR 1,90 trillion at the end of III-2020, compared to industry income at the end of the third quarter of the following year (2019) which was IDR. 4,42 trillion. Meanwhile, PT Matahari Department Store posted a net loss of 616,60 billion in the third quarter of 2020. This value is inversely proportional to the period at the end of September 2019 where the industry still pocketed a profit of IDR. 1,19 trillion. Industrial income also plunged $57.49 \%$ year-on-year
(YoY), with a position at the end of the third quarter of 2020 valued at IDR 3,32 trillion. This amount is far below the income in the same period last year, Rp. 7 , 82 trillion.

The business units of PT Ramayana Lestari Sentosa Tbk and PT Matahari Department Store have suspended operations. Judging from the performance of the company Ramayana and Matahari Department Store facing an increase and decrease in net profit, this industry was facing a decline in profit in 2019 until now in 2021, a reduction in profit of PT Matahari Department Store of 1.16 trillion and PT Ramayana Lestari Sentosa Tbk with a profit depreciation of 138, 87 billion, which is caused by the problem of covid 19, the lasting result of this covid 19. PT Ramayana Lestari Sentosa Tbk carried out some store closures in connection with the decline in net profit. It is undeniable that behind the closing of some outlets, the company also took several steps such as Termination of Employment for 100 employees. 
That is not all; moreover, PT Matahari Department Store has decided to reduce the number of outlets from 153 to 147 by 2020 . In other words, the industry has closed six outlets, bringing the total to 13 outlets. Matahari Department Store management is also looking for opportunities to open stores selectively, renovating existing stores to boost productivity. The group also needs to invest in taking over the aging infrastructure.

This study compared the financial ratios between PT Ramayana Lestari Sentosa Tbk and PT Matahari Department Store. Therefore, this research is expected to contribute to the parties who invest in the company as one of the considerations in making investment decisions.

\section{LITERATURE REVIEW}

Financial ratios are an activity to compare the numbers in the financial statements [2]. Comparisons can be made between one component and another; then, the numbers can be reached in the form of numbers in one period or several periods. A liquidity ratio can describe its ability to pay its short-term obligations [3]. The solvency ratio is a picture of the ability to pay the obligation in long-term companies [4]. Activity ratio is used to measure the efficiency level of utilization of company resources in carrying out daily activities [5].

\section{METHODOLOGY}

\subsection{Type of Research}

Using qualitative research is a phenomenon that occurs through data collection and analysis that occurs at PT Ramayana Lestari Sentosa Tbk and PT Matahari Department Store. Data taken from the IDX information disclosure are financial statements from 2018-2020.

\subsection{Data Analysis Techniques}

\subsubsection{Liquidity}

Current Ratio $=\frac{\text { Current Asset }}{\text { Current Liabilities }} \times 100 \%$

Cash Ratio $=\frac{\text { Cash }+ \text { Effect }}{\text { Current Liabilities }} \times 100 \%$

Quick Ratio

$$
=\frac{\text { Cash }+ \text { Effect }+ \text { Receivable }}{\text { Current Liabilities }} \times 100 \%
$$

\subsubsection{Solvability}

Debt to Asset Ratio

$$
=\frac{\text { Total Liabilities }}{\text { Total Assets }} \times 100 \%
$$

Debt Equity Ratio

$$
=\frac{\text { Current Asset Total Liabilities }}{\text { Equity }} \times 100 \%
$$

\subsubsection{Activity}

Total Asset Turnover $=\frac{\text { Sales }}{\text { Total Assets }} \times 100 \%$

Fixed Asset Turnover $=\frac{\text { Sales }}{\text { Fixed Assets }} \times 100 \%$

Inventory Turnover $=\frac{\text { Sales }}{\text { Inventory }} \times 100 \%$

Average Collection Period Ratio

$$
=\frac{\text { Receivable } \times 365}{\text { Sales }} \times 100 \%
$$

\section{RESULTS AND DISCUSSION}

Table 1. Financial Statements PT Ramayana Lestari Tbk SENSTOSA

\begin{tabular}{|c|c|c|c|}
\hline Year & Sales & Net Income & Equity \\
\hline 2018 & 5.739 .553 & 587.105 & 3.827 .465 \\
\hline 2019 & 5.596 .398 & 647.898 & 4.168 .930 \\
\hline 2020 & 4.839 .058 & $(138.874)$ & 3.718 .744 \\
\hline
\end{tabular}

Table 2. Financial Statements PT Matahari Department Store

\begin{tabular}{|c|c|c|c|}
\hline Year & Sales & Net Income & Equity \\
\hline 2018 & 10.245 .173 & 1.097 .332 & 1.815 .828 \\
\hline 2019 & 10.376 .431 & 1.366 .884 & 1.746 .627 \\
\hline 2020 & 4.839 .058 & $(873.181)$ & 581.118 \\
\hline
\end{tabular}


According to the data above, PT Ramayana Lestari Sentosa Tbk and PT Matahari Department Store experienced an increase and decrease in profit. In 2018 PT Ramayana Lestari Sentosa tbk had a total of Rp. 587,105, then in 2019, it jumped to Rp. 647,898 , then in 2020, it decreased by Rp. 138,874 . in 2018 PT Matahari Department Store had a total net profit of Rp. 1,097,332 then in 2019 it increased to Rp. $1,366,884$, but in 2019 PT Matahari Department Store decreased by Rp. 873,181 . Therefore, we will analyze these two companies.

\subsection{Liquidity Ratio}

There is some liquidity ratio, including:

Table 3. Result Current Ratio PT Ramayana Lestari Sentosa Tbk

\begin{tabular}{|c|c|c|c|}
\hline \multicolumn{4}{|c|}{ PT. Ramayana Lestari Sentosa Tbk } \\
\hline & \multicolumn{3}{|c|}{ Year } \\
\hline & 2020 & 2019 & 2018 \\
\hline Total & \multirow{3}{*}{$3,4 \%$} & \multirow{3}{*}{$3,5 \%$} & \multirow{3}{*}{$3,2 \%$} \\
\hline Assets & & & \\
\hline Turn Over & & & \\
\hline \multicolumn{4}{|c|}{ PT. Matahari Department Store } \\
\hline & \multicolumn{3}{|c|}{ Year } \\
\hline & 2020 & 2019 & 2018 \\
\hline Total & \multirow{3}{*}{$0,5 \%$} & \multirow{3}{*}{$1 \%$} & \multirow{3}{*}{$1,1 \%$} \\
\hline Assets & & & \\
\hline Turn Over & & & \\
\hline
\end{tabular}

In 2018, PT Ramayana Lestari Sentosa Tbk showed a $3.2 \%$ current ratio, in $20193.5 \%$ and 2020 $3.4 \%$, and PT Matahari. Department Store showed a current ratio of $1.1 \%$, in $20191 \%$ while in $20200.5 \%$. From data from PT Ramayana Lestari Sentosa Tbk that in 2018 to 2019 , the current ratio is above 1 , which means that current assets can cover all current debts. This means that current assets are far above current liabilities [9]. Then PT Matahari Department Store, it can be seen from 2018 to 2019 that the current ratio is above 1 , which means that current assets can cover all current debts. However, in 2020 the current ratio is below 1 , which means that current assets cannot cover all current liabilities.
Table 4. Result Cash Ratio PT Ramayana Lestari Sentosa Tbk

\begin{tabular}{|c|c|c|c|}
\hline \multicolumn{3}{|c|}{ PT. Ramayana Lestari Sentosa Tbk } \\
\hline \multirow{2}{*}{} & 2020 & 2019 & 2018 \\
\cline { 2 - 4 } & PT. Matahari Department Store \\
\hline Cash Ratio & $167 \%$ & $194 \%$ & $178 \%$ \\
\hline \multicolumn{3}{|c|}{ Year } \\
\cline { 2 - 4 } & 2020 & 2019 & 2018 \\
\hline $\begin{array}{c}\text { Total } \\
\text { Assets } \\
\text { Turn Over }\end{array}$ & $20,4 \%$ & $45,1 \%$ & $43,2 \%$ \\
\hline
\end{tabular}

From the data above, in 2018, PT Ramayana Lestari Sentosa Tbk showed a cash ratio of $178 \%$, in 2019 194\% and $2020167 \%$ and at PT Matahari Department Store showing a cash ratio of $43.2 \%$, in 2019 it was $45.1 \%$ and in 2020 by $20.4 \%$. From data from PT Ramayana Lestari Sentosa Tbk in 2018 to 2020 , the cash ratio reached more than $100 \%$, which means the company is said to be healthy. Then PT Matahari Department Store, it can be seen from 2018 to 2020 that the cash ratio is below $100 \%$, this shows that the company is not healthy. The bigger the ratio, the better even though the $100 \%$ ratio is not exceeded, but $100 \%$ is healthy [10].

Table 5. Quick Ratio PT Ramayana Lestari Sentosa Tbk

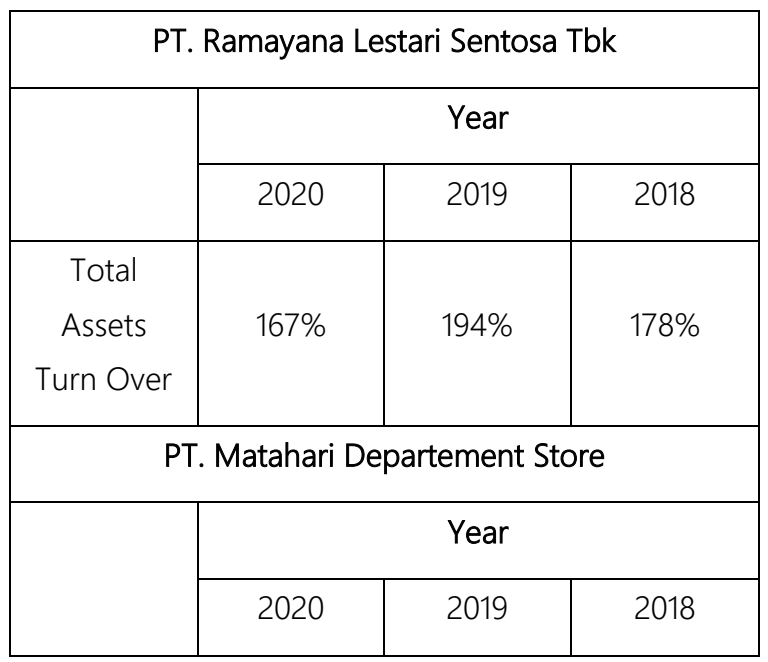




\begin{tabular}{|c|c|c|c|}
\hline $\begin{array}{c}\text { Total } \\
\text { Assets } \\
\text { Turn Over }\end{array}$ & $20 \%$ & $40 \%$ & $47,9 \%$ \\
\hline
\end{tabular}

From the above data in 2018, PT Ramayana Lestari Sentosa Tbk showed a quick ratio of $178 \%$, while 2019 was $194 \%$ and in 2020 was $167 \%$, and PT Matahari Department Store showed a quick ratio of $47.9 \%$, in $201940 \%$ and 2020 20\%. From data from PT Ramayana Lestari Sentosa Tbk in 2018 to 2020, the quick ratio reached more than $100 \%$, which means the company is said to be healthy. Then at PT Matahari Department Store, it can be seen that from 2018 to 2020 , the quick ratio is below $100 \%$, which shows that the company is not healthy [11].

\subsection{Solvency Ratio}

There are some solvency ratios include:

Table 6. Total Debt to Asset Ratio PT Ramayana Lestari Sentosa Tbk

\begin{tabular}{|c|c|c|c|}
\hline \multicolumn{4}{|c|}{ PT. Ramayana Lestari Sentosa Tbk } \\
\hline \multirow{2}{*}{} & 2020 & 2019 & 2018 \\
\cline { 2 - 4 } & $0,2 \%$ & $0,2 \%$ & $0,2 \%$ \\
\hline Cash Ratio & \multicolumn{3}{|c|}{ Year } \\
\hline \multicolumn{2}{|c|}{ PT. Matahari Departement Store } \\
\cline { 2 - 4 } & 2020 & 2019 & 2018 \\
\hline $\begin{array}{c}\text { Total } \\
\text { Assets Turn } \\
\text { Over }\end{array}$ & $0,9 \%$ & $0,6 \%$ & $0,6 \%$ \\
\hline
\end{tabular}

From the data above in 2018 PT Ramayana Lestari Sentosa Tbk that the results of the Total Debt to Asset Ratio are 0.2\%, while in $20190.2 \%$ and 2020 $0.2 \%$ and at PT Matahari Department Store, the results of the Total Debt to Asset Ratio were $0.6 \%$, while in 2019 it was $0.6 \%$ and in 2020, it was $0.9 \%$. From the data above, it can be seen that at PT Ramayana Lestari Sentosa Tbk in 2018, 2019, and 2020, the total debt to asset ratio is below 1, which means that assets can cover the company's debt because the 3-year ratio is small and can be said to be safe. Then at PT Matahari Department Store, it can be seen that in 2018, 2019, and 2020, the total debt to asset ratio was below number 1; this shows that assets can cover the company's debt because the ratio in 3 years is small and can be said to be safe. The smaller the ratio, the safer (solvable) [12].
Table7. Total Debt to Equity Ratio PT Ramayana Lestari Sentosa Tbk

\begin{tabular}{|c|c|c|c|}
\hline \multicolumn{3}{|c|}{ PT. Ramayana Lestari Sentosa Tbk } \\
\hline \multirow{2}{*}{} & 2020 & 2019 & 2018 \\
\cline { 2 - 4 } & $0,1 \%$ & $0,2 \%$ & $0,2 \%$ \\
\hline Cash Ratio & \multicolumn{3}{|c|}{ Year } \\
\hline \multicolumn{3}{|c|}{ PT. Matahari Departement Store } \\
\cline { 2 - 4 } & 2020 & 2019 & 2018 \\
\hline $\begin{array}{c}\text { Total } \\
\text { Assets } \\
\text { Turn Over }\end{array}$ & $10 \%$ & $2,6 \%$ & $2,7 \%$ \\
\hline
\end{tabular}

From the data above, in 2018 PT Ramayana Lestari Sentosa Tbk that Total Debt to Equity Ratio $0.2 \%$, in $20190.2 \%$ while in $20200.1 \%$ and at PT Matahari Department Store shows Total Debt to Equity $2.7 \%$, in 2019 it was $2.6 \%$ while in 2020 it was $10 \%$. From data from PT Ramayana Lestari Sentosa Tbk in 2018, 2019, and 2020 the total debt to equity ratio is below 1 , which means that the amount of debt is smaller than its capital, and it can be said that the company is safe. Then at PT Matahari Department Store, it can be seen that in 2018, 2019, and 2020, the total debt to equity ratio was above number 1 ; it can be said that debt is more significant than own capital, and the company can be said to be unsafe. The smaller the portion of the debt to money, the safer it is [13].

\subsection{Activity Ratio}

There are several activity ratios include:

Table 8. Debt Assets Turn Over PT Ramayana Lestari Sentosa Tbk.

\begin{tabular}{|c|c|c|c|}
\hline \multicolumn{3}{|c|}{ PT. Ramayana Lestari Sentosa Tbk } \\
\hline & \multicolumn{3}{|c|}{ Year } \\
\cline { 2 - 4 } & 2020 & 2019 & 2018 \\
\hline $\begin{array}{c}\text { Total } \\
\text { Assets } \\
\text { Turn Over }\end{array}$ & $0,4 \%$ & $0,9 \%$ & $1 \%$ \\
\hline \multicolumn{3}{|c|}{} & \\
\hline \multicolumn{2}{|c|}{ PT. Matahari Departement Store } \\
\hline
\end{tabular}




\begin{tabular}{|c|c|c|c|}
\hline & \multicolumn{3}{|c|}{ Year } \\
\cline { 2 - 4 } & 2020 & 2019 & 2018 \\
\hline $\begin{array}{c}\text { Total } \\
\text { Assets } \\
\text { Turn Over }\end{array}$ & $7,8 \%$ & $2,1 \%$ & $2 \%$ \\
\hline
\end{tabular}

From the data above, in 2018, PT Ramayana Lestari Sentosa Tbk showed a Total Debt Assets Turn Over of $1 \%$, in $20190.9 \%$ while in 2020 it was $0.4 \%$, and at PT Matahari Department Store showed a Total Debt Asset Turn Over of 2\%, in 2019 2, 1\% while in $20207.8 \%$. From the data above, it can be seen that PT Ramayana Lestari Sentosa Tbk in 2018, 2019, and 2020 decreased from year to year; in 2018, the ratio was at number 1 , but in the following year, the ratio decreased and was below number 1 . The ratio results are relatively low, so management must re-evaluate its strategies from marketing, spending, and capital in the company. Then at PT Matahari Putra Prima Tbk, it can be seen that in 2018,2019, and 2020, there was an increase from year to year, and the results of the 3 -year ratio were pretty high in 2020 because the presentation in the three years was above 1 , this shows that management can be said to be good [1].

Table 9. Fixed Assets Turn Over PT Ramayana Lestari Sentosa Tbk.

\begin{tabular}{|c|c|c|c|}
\hline \multicolumn{4}{|c|}{ PT. Ramayana Lestari Sentosa Tbk } \\
\hline & \multicolumn{3}{|c|}{ Year } \\
\hline & 2020 & 2019 & 2018 \\
\hline $\begin{array}{l}\text { Total } \\
\text { Assets Turn } \\
\text { Over }\end{array}$ & $2,5 \%$ & $5 \%$ & $4,9 \%$ \\
\hline \multicolumn{4}{|c|}{ PT. Matahari Departement Store } \\
\hline & \multicolumn{3}{|c|}{ Year } \\
\hline & 2020 & 2019 & 2018 \\
\hline $\begin{array}{l}\text { Total } \\
\text { Assets Turn } \\
\text { Over }\end{array}$ & $5,6 \%$ & $7,1 \%$ & $8,2 \%$ \\
\hline
\end{tabular}

From the data above, in 2018, PT Ramayana Lestari Sentosa Tbk showed Fixed Assets Turn Over of $4.9 \%$, in $20195 \%$ and $20202.5 \%$ and at PT Matahari Department Store showed Fixed Assets Turn Over $8.2 \%$, in $20197.1 \%$ while in 2020 it was $5.6 \%$. It can be seen from the data that PT Ramayana Lestari Sentosa Tbk in 2018 was $4.9 \%$, and in 2019 it increased, then in 2020, it decreased considerably to $2.5 \%$. So, the effectiveness of the company is using its fixed assets can be said to be still good. Then at PT Matahari Department Store, it can be seen in 2018, 2019, and 2020 that there was a decline from year to year. However, the ratio results are still safe because the ratio in the three years is above 1 , and the company's effectiveness in using fixed assets is still good. The higher this ratio means, the more significant the proportion of these assets [14].

Table 10. Inventory Turn Over PT Ramayana Lestari Sentosa Tbk

\begin{tabular}{|c|c|c|c|}
\hline \multicolumn{3}{|c|}{ PT. Ramayana Lestari Sentosa Tbk } \\
\hline \multirow{2}{*}{$\begin{array}{c}\text { Total } \\
\text { Assets } \\
\text { Turn Over }\end{array}$} & 2020 & 2019 & 2018 \\
\cline { 2 - 4 } & $5,1 \%$ & $7 \%$ & $6,6 \%$ \\
\hline \multirow{2}{*}{ PT. Matahari Departement Store } \\
\hline \multirow{2}{*}{$\begin{array}{c}|c| \\
\text { Assets }\end{array}$} & Year & \\
\cline { 2 - 4 } & 2020 & 2019 & 2018 \\
\hline Turn Over & & $9,3 \%$ & $7,9 \%$ \\
\hline
\end{tabular}

From the data above, in 2018, PT Ramayana Lestari Sentosa Tbk showed an Inventory Turn Over of $6.6 \%$; in 2019, it increased $7 \%$, while in 2020, it decreased again by $5.1 \%$. PT Matahari Department Store showed Inventory Turn Over $7.9 \%$ in 2019. decreased $9.3 \%$, and in 2020 , it fell by $5.4 \%$. From the data of PT Ramayana Lestari Sentosa Tbk above, in 2020 , there was a considerable decline to $5.1 \%$. However, these ratio results are still said to be high, so inventory management is still reasonably effective. Then at PT Matahari Department Store, it can be seen that in 2020 it decreased considerably to $5.4 \%$. However, the ratio results are still high because they are still quite significant, and it can be said that inventory management is still reasonably effective [15]. 
Table 11. Receivable Turn Over PT Ramayana Lestari Sentosa Tbk

\begin{tabular}{|c|c|c|c|}
\hline \multicolumn{4}{|c|}{ PT. Ramayana Lestari Sentosa Tbk } \\
\hline & \multicolumn{3}{|c|}{ Year } \\
\hline & 2020 & 2019 & 2018 \\
\hline $\begin{array}{c}\text { Total } \\
\text { Assets } \\
\text { Turn Over }\end{array}$ & $5,1 \%$ & $7 \%$ & $6,6 \%$ \\
\hline \multicolumn{4}{|c|}{ PT. Matahari Departement Store } \\
\hline & \multicolumn{3}{|c|}{ Year } \\
\hline & 2020 & 2019 & 2018 \\
\hline $\begin{array}{c}\text { Total } \\
\text { Assets } \\
\text { Turn Over }\end{array}$ & $5,4 \%$ & $9,3 \%$ & $7,9 \%$ \\
\hline
\end{tabular}

From the above data in 2018, PT Ramayana Lestari Sentosa Tbk showed a Receivable Turn Over of 300\%, in $2019315 \%$ and $2020112 \%$, and PT Matahari Department Store showed a Receivable Turn Over of $119 \%$, in 2019 of $182 \%$ and 2020 by $132 \%$.

The higher the turnover, the more effective the management of receivables [16]. From the data of PT Ramayana Lestari Sentosa Tbk above in 2019, it increased to $315 \%$ then experienced a considerable decline in 2020 to $112 \%$; the results of this ratio are still reasonably safe, although the percentage in 2020 decreased quite drastically, the ratio results are still above $100 \%$ then the receivables can be said to be still effective. Then at PT Matahari Department Store, it can be seen that in 2019 it increased to $182 \%$ then decreased quite far in 2020 to $132 \%$; the results of this ratio are still relatively safe, although the percentage in 2020 decreased quite drastically, the ratio results are still above $100 \%$, the receivables are still considered adequate.

\section{CONCLUSION}

After analyzing the financial statements to measure the performance of the financial statements after the Pandemic, PT Matahari Lestari Sentosa and PT Ramayana Putra Prima experienced a significant decline in 2020.

The financial performance of PT Ramayana Lestari Sentosa Tbk was based on a good liquidity ratio so that the company could cover all current debt, while based on the solvency ratio, it can be said to be safe, and based on the activity ratio, how to measure using the Total Assets Turn Over ratio the company has decreased, so management must re-evaluate its strategies both from marketing, spending, and capital in the company. However, in other ratios, the company's inventory management is quite effective. The financial performance of PT Matahari Department Store based on the liquidity ratio is not good, so the company cannot cover all current debts. Based on the solvency ratio, it can be said to be safe. Because when measured using the ratio of the Total Debt to Equity Ratio is not safe, while measured by the ratio of the Total Debt to Asset Ratio the company can be said to be safe. Moreover, based on the ratio of inventory management activities that can be said to be good, receivables are still reasonably practical.

\section{REFERENCES}

[1] M. Irman and A. A. Purwati, "Analysis On The Influence Of Current Ratio, Debt to Equity Ratio and Total Asset Turnover Toward Return On Assets On The Otomotive and Component Company That Has Been Registered In Indonesia Stock Exchange Within 2011-2017," Int. J. Econ. Dev. Res., vol. 1, no. 1, pp. 36-44, 2020, doi: 10.37385/ijedr.v1i1.26.

[2] M. Kumbirai and R. Webb, "A financial ratio analysis of commercial bank performance in South Africa," African Rev. Econ. Finance., vol. 2, no. 1, pp. 30-53, 2013.

[3] A. Husna and I. Satria, "Effects of Return on Asset, Debt To Asset Ratio, Current Ratio, Firm Size, and Dividend Payout Ratio on Firm Value," Int. J. Econ. Finance. Issues, vol. 9, no. 5, pp. 50-54, 2019, DOI: 10.32479/ijefi.8595.

[4] Z. Wang and J. Sarkis, "Corporate social responsibility governance, outcomes, and financial performance," J. Clean. Prod., vol. 162, pp. 1607-1616, 2017, DOI: 10.1016/j.jclepro.2017.06.142.

[5] L. Muhammad, "Liquidity Risk and Profitability of Listed Deposit Money Banks in Nigeria," Res. J. Financ. Account., vol. 6, no. 1, pp. 42-52, 2017, DOI: $10.7176 / \mathrm{rjfa} / 11-$ 8-13.

[6] A. A, Aziz and R. Abdul, "The Relationship between Solvency Ratios and Profitability Ratios: Analytical Study in Food Industrial Companies listed in Amman Bursa," Int. J. Econ. Finance. Issues, vol. 7, no. 2, pp. 86-93, 2017, [Online]. Available: http: www.econjournals.com. 
[7] A. Supami, "The effect of debt to equity ratio and current ratio on firm value.," J. Account. Bus. Educ., vol. 8, no. 2, pp. 1-13, 2021.

[8] Y. Ferdiawan and A. Firmansyah, "Pengaruh Political Connection, Foreign Activity, Dan Real Earnings Management Terhadap Tax Avoidance Pendapatan Perpajakan merupakan," J. Ris. Akunt. Keuang., vol. 5, no. 3, pp. 1601-1624, 2017.

[9] O. Podolianchuk, T. Plakhtii, and N. Gudzenko, "Current Liabilities and Their Accounting in the Attracted Capital Management System," Balt. J. Econ. Stud., vol. 5, no. 3, p. 159, 2019, DOI: 10.30525/2256-0742/2019-5-3-159-169.

[10] K. I. Inaba, "Corporate cash and governance: A global look into publicly-traded companies' aggregate cash ratios," Int. Rev. Financ. Anal., vol. 78, p. 101808, 2021, DOI: 10.1016/j.irfa.2021.101808.

[11] "Measuring Small Business Liquidity: An Alternative to Current and Quick Ratios," J. Small Bus. Manag., vol. 16, 1978.

[12] I. Welch, "Two common problems in capital structure research: The financial-debt-to-asset ratio and issuing activity versus leverage changes," Int. Rev. Financ., vol. 11, no. 1, pp. 117, 2011, DOI: $10.1111 /$ j.14682443.2010.01125.x.

[13] A. H. Dita and I. Murtaqi, "The Effect of Net Profit Margin, Price To Book Value and Debt To Equity Ratio to Stock Return In The Indonesian Consumer Goods Industry," J. Bus. Manag., vol. 3, no. 3, pp. 305-315, 2014, [Online]. Available: http://journal.sbm.itb.ac.id/index.php/jbm/article/ view/1214.

[14] O. Couwenberg, "Financial Distress," Wiley Encycl. Manag., vol. 2, pp. 1-3, 2015, doi: 10.1002/9781118785317.weom040039.

[15] M. I. Sunjoko and E. J. Arilyn, "Effect of inventory turnover, total asset turnover, fixed asset turnover, current ratio and average collection period on profitability," J. Bisnis Dan Akunt., vol. 18 , no. 1, pp. 79-83, 2016.
[16] A. E. A. Manullang, D. Togatorop, P. R. D. Purba, E. A. Y. Manik, E. N. Simorangkir, and R. K. Lase, "The Significance of Accounts Receivable Turnover, Debt to Equity Ratio, Current Ratio to The Probability of Manufacturing Companies," Int. J. Soc. Sci. Bus., vol. 4, no. 3, p. 464, 2020, doi: 10.23887/ijssb.v4i3.27874. 